\title{
Field curing methods and storage duration affect the quality of hay from six rangeland grass species in Kenya
}

\author{
O. K. Koech ${ }^{1 *}$, R. N. Kinuthia', G. N. Karuku', S. M. Mureithi ${ }^{1}$ and R. Wanjogu²
}

\begin{abstract}
Introduction: Rangelands are important source of pasture for livestock in Kenya since time immemorial to pastoral households. However, seasonality on forage availability has been a big challenge in meeting animals' feed requirements. This demands harvest and storage of pastures for use during dry seasons. Hay making has been done to bridge this forage deficit periods. However, hay quality in the rangelands is affected by curing methods, phonological stage at harvest, and the storage duration. We therefore evaluated the effect of field curing and storage duration on the quality (Crude Protein (CP)) of hay from six rangeland grasses in Kenya.

Methods: The grasses evaluated are Chloris roxburghiana, Eragrostis superba, Enteropogon macrostachyus, Cenchrus ciliaris, Chloris gayana, and Sorghum sudanense. These grasses are the common species in the rangelands of Kenya and have been promoted in the past for hay making and reseeding interventions. The grasses were harvested at the mature flowering stage (12 weeks phenological stage), which is a period that provides high biomass without much effect on quality as practiced in the study area. The grasses were then cured in the field for 1, 2, and 3 days before baling and stored indoors for 12, 24, and 36 weeks. Samples were taken for CP content determination at the three periods following Macro-Kjeldahl Method.
\end{abstract}

Results: There was significant decline $(p \leq 0.05)$ in crude protein content in all the grass species with storage periods. Curing period did not affect the CP content for all the species at a given storage period; however, 3 days curing changed the hay color from green to brownish which reduces palatability and consequently reduced feed intake. Storage period of over 12 weeks adversely lowered CP to less than $6 \%$ for all the species which is the required minimum level for animal under production and maintenance. S. Sudanense had significantly higher decline in CP after 24 weeks storage compared to the other species.

Conclusions: Therefore, hay from the six grass species harvested at mature flowering stage (12-week phonological stage) and stored longer than 12 weeks supplies the animals with low CP. Also, to maintain palatability, 1-2 days curing is recommended for the six grass species.

Keywords: Grass quality, Range grasses, Semi-arid rangelands, Grass storage, Grass curing, Kenya

\footnotetext{
* Correspondence: okkoech@yahoo.com

'Department of Land Resource Management and Agricultural Technology, Range Management Section, University of Nairobi, P.O. Box 209053-00625, Nairobi, Kenya

Full list of author information is available at the end of the article
} 


\section{Introduction}

Rangelands play an important role in providing livestock feed resources; however, these areas have been facing many challenges resulting from increasing levels of seasonality as a consequence of the changing climatic conditions (McDermott et al. 2010; Thornton and Herrero 2014). The seasonality has resulted to periods of surplus and shortage in livestock feed supply. Consequently, hay production and conservation has been practiced for ages as one of the adaptation mechanisms to bridging the animal feed shortages in the rangelands. However, effect of the methods used in handling from the farm to storage on the quality of the end product fed to animals is little understood in the rangelands of Kenya.

Production and conservation of forages, including crop residues, for feeding during periods of feed scarcity, is an ages-old practice in virtually all livestock producing systems of the world (Ndathi et al. 2011). Hay and silage-making are some of the oldest and most popular methods of conserving forages (Suttie 2000). The main goal in production and conservation of any plant material for feeding to livestock later is to minimize loss of quantity and quality during harvesting, storage, and feeding (Buskirk et al. 2003; Mackie 2004). Under good husbandry practices, forage materials when growing can be of very high quality but lose most of it between harvesting, transportation, storage, and feeding but mostly higher during storage (Roberts et al. 2009; Bernués et al. 2011).

Prevailing weather conditions during the time of cutting, curing, and baling can have huge adverse effect on the forage material. For example, alfalfa hay DM dropped by up to $22 \%$ when exposed to about $10 \mathrm{~mm}$ of rainfall during curing (Rankin and Undersander 2004). According to Rankin and Undersander (2004), prevailing weather conditions affect forage quality through (i) plant respiration that reduces soluble carbohydrates and energy content during storage; (ii) leaching of soluble carbohydrates, protein, and minerals under unprotected storage; (iii) leaf shattering and loss of highly digestible proteins; (iv) microbial activity which metabolizes soluble carbohydrates, reducing forage energy content, and possibly producing harmful metabolites; and finally (v) color change through bleaching and excessive drying reducing palatability of the hay (Roberts 1995). Moldy hay can be a health hazard to livestock due to potential toxicity (Tangni et al. 2013). In a few cases, hay baled at high-moisture content can spontaneously heat to combustion (Rotz and Muck 1994).

In Kenya, several range grasses have been promoted for pasture production with the main species of interest being Chloris roxburghiana, Eragrostis superb, Enteropogon macrostachyus, Cenchrus ciliaris, Chloris gayana, Bracharia brizantha, and Sorghum sudanense (Ndathi et al. 2012; Ndathi et al. 2013; Mganga et al. 2015).
These species have been highly promoted for fodder bulking through hay making in the rangelands of Kenya.

Grass production for storage as hay requires a lot of care from harvest handling which may determine the quality after storage to feeding. Crude protein $(\mathrm{CP})$ has been used widely as proxy for feed quality analysis and has been reported to decline depending on post harvest handling. The same nutrient has been reported to be among the most limiting in the drylands especially during the dry seasons. Mechanisms of handling and storage to reduce its decline in forage during handling are imperative. The measurement of this vital nutrient that is most limiting in hay was therefore picked in this study and was measured from different curing methods and storage periods. We therefore evaluated the effect of stage of maturity (mature flowering at 12-week phonological stage) and duration of curing before storage for periods of 2,12, 24, and 36 weeks on the quality of hay. The selected grass species in were C. roxburghiana (CR), E. superb (ES), E. macrostachyus (EM), C. ciliaris (CC), C. gayana (CG), and S. sudanense (SB). The six were selected from their ranking as best species for hay and reseeding in Rangelands. This study aimed to provide vital information on hay handling from harvest to storage in Kenyan rangelands for quality preservation of pastures that has high demand during the dry seasons. The study sort to answer our hypothesis that hay curing and storage affects the quality of the end product in the Kenyan rangelands.

\section{Methods}

\section{Study area}

The study was done in the arid rangelands in South Eastern Kenya, within Bura Irrigation Scheme located in Tana River County, coordinates $1^{\circ} 30^{\prime} \mathrm{S}, 40^{\circ} 0^{\prime} \mathrm{E}, 1.5^{\circ} \mathrm{S}$ $40^{\circ} \mathrm{E}$ (Fig. 1). The experimental period was from September 2012 to January 2013. The area is generally hot and dry with daily temperatures of between 20 and $38{ }^{\circ} \mathrm{C}$ and the highest months being between February and April. Rainfall pattern is bimodal with long rains occurring in April-June and short rains in NovemberDecember. The rainfall is erratic in nature with a longterm mean between 220 and $500 \mathrm{~mm}$. Majority of the population $(70 \%)$ in the county live below the absolute poverty line have been on permanent food relief recipient for the last 10 years (GoK 2005). The study county is divided into three livelihood zones, namely, pastoral, agro-pastoral (mixed farming), and marginal mixed farming. Livestock production is the main economic activity in the county under extensive pastoral system.

The soil types are vertisols and vertic fluvisols associated with swelling and forming ponds during wet seasons with low infiltration rates from the sealing by high clay content. During dry seasons, the soil dry out and develop cracks. 


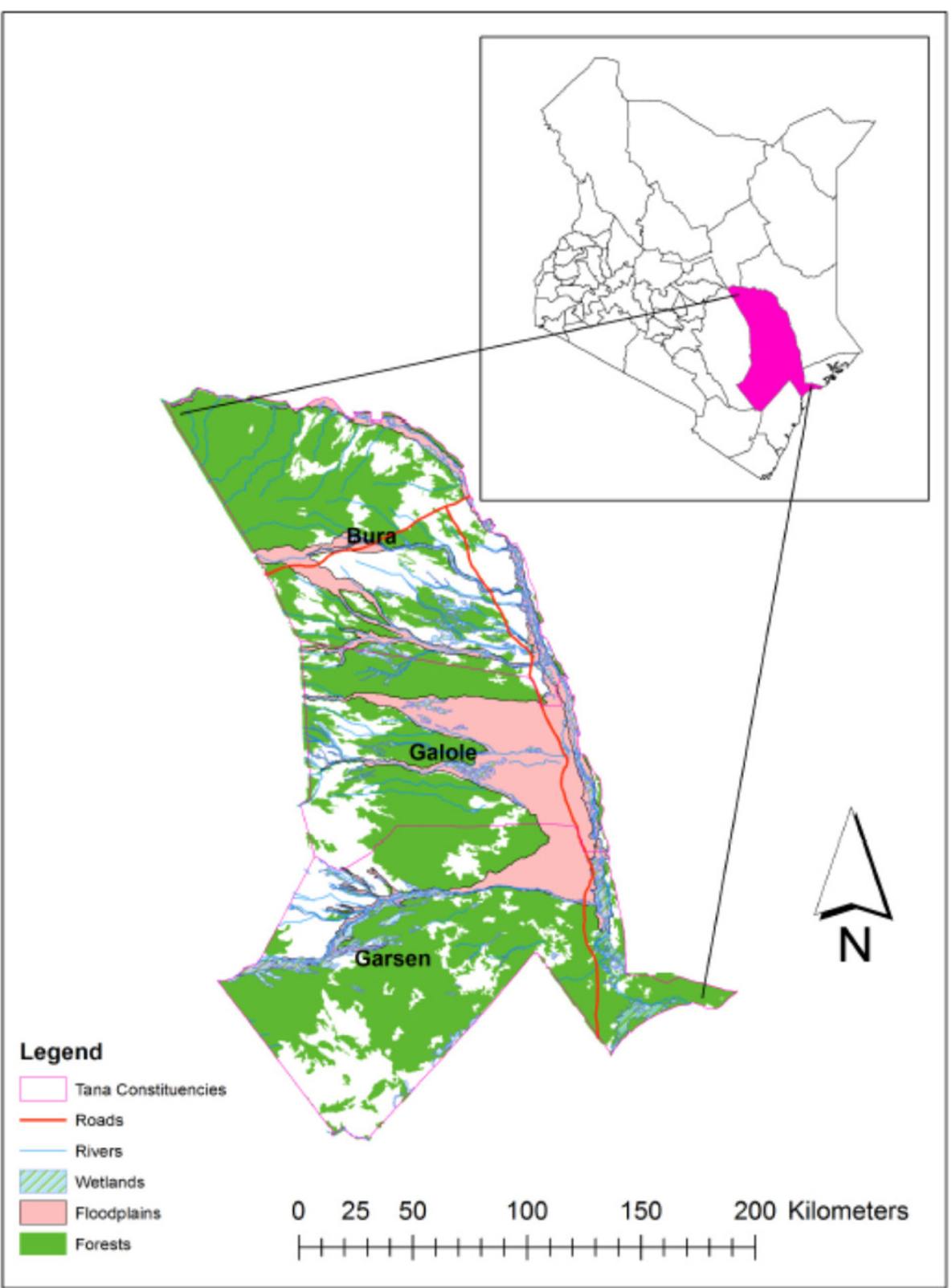

Fig. 1 Study country-Kenya (top right) in relation to study area-Tana. Source: Author developed using GIS

At the hinterlands are shallow and have undergone seasons of trampling by livestock, thus are easily eroded during rainy seasons. This has necessitated reseeding with range grass that is going on at the present to increase pasture availability.

Vegetation in the county ranges from thorny thickets of acacia trees to shrubs along the riverine ecosystems. Shrubs and native grasses dominate the most parts of the grazing areas in the county, with trees and perennial range grasses selected for this study dominating the wetter parts along the delta. The county is also affected by invasive species such as Prosopis juliflora, commonly known as "Mathenge." The area has also been experiencing conflicts over pasture lands during dry seasons among the pastoral communities of Somali, Wardei, Pokomo, and Oromo who inhabit the area. These conflicts have resulted to increased need for pasture production and conservation to abate the conflicts.

\section{Land preparation, experimental design, and agronomic procedure}

The grass species were grown in land that had not been cultivated for the previous two seasons which was cleared, and half acre plot ploughed by tractor and 
harrowed to a fine tilth. The land was later divided into 18 subplots measuring $5 \times 5 \mathrm{~m}$ with $1 \mathrm{~m}$ boundary between the subplots. The experimental design was completely random design (CRD) where the subplots were then randomly allocated the six grass species with three replicates. The grass seeds were sourced from Kenya Agricultural Research Institute (KALRO), Kiboko Station. Before planting, the grass seeds were tested for germination rates using the method described by ISTA (1976). The germination rates obtained were used to determine the sowing rates of $4 \mathrm{~kg} / \mathrm{ha}$ for each species such that $>75 \%$ germination rates were obtained. Sowing was done manually by broadcast. All other routine pasture husbandry practices such as weeding were conducted at the same time for all the plots during the establishment.

Sample preparation, chemical analyses, and data analysis Samples of forage materials were harvested from the plots at week 12 growth periods. The material was divided into three equal portions from each subplot, one portion hand-baled after 1,2 , and 3 days curing periods. The materials (bales) collected each day were stored indoors in an iron sheet-roofed store house with wooden walls. Prior to storage, the moisture content was determined using 50-g subsamples for each species at the three curing periods, which were oven dried and percent moisture at storage determined. To avoid mix-ups in the store, the experimental materials were carefully tagged before being stored. To determine the effect of storage period, experimental material batches from each of the curing treatment levels were sampled at 12, 24, and 36 weeks storage period using core sampling method as described by Rotz and Abrams (1988) and taken for CP analysis following Macro-Kjeldahl Method as describe by Association of Analytical Chemists (AOAC 1990; 2005). All chemical analyses were conducted in three replicates per grass species for all the three curing periods and four storage period at the Department of Animal Production, University of Nairobi.

The data were analyzed using SAS Version 9. Statistical analyses included analysis of variance (ANOVA) at $95 \%$ confidence level. Where significant differences were detected, the means were separated by the least significant difference (LSD) method at $5 \%$ probability level.

\section{Results}

The results showed no significant difference $(p \geq 0.05)$ in percentage $\mathrm{CP}$ content for all the grass species at the three curing periods at a given storage period (Table 1). However, there was a significant $(p \leq 0.05)$ decline in percentage $\mathrm{CP}$ with storage from 24 weeks onwards for all the grass species in the three curing periods. The 2-week storage period yielded 7-8 \% CP for all the
Table 1 Crude proteins (\% CP) of selected grasses harvested at 12th-week phenological stage, cured for 1, 2, and 3 days, before indoor storage for 2, 12, 24, and 36 weeks

\begin{tabular}{llll}
\hline \multicolumn{4}{l}{$\%$ CP } \\
Curing period & 1 day & 2 days & 3 days \\
Week 2 & & \\
CR & $7.5^{\mathrm{a}} \pm 2.1$ & $7.8^{\mathrm{a}} \pm 1.4$ & $7.5^{\mathrm{a}} \pm 3.1$ \\
ES & $7.0^{\mathrm{a}} \pm 1.7$ & $7.8^{\mathrm{a}} \pm 3.2$ & $7.7^{\mathrm{a}} \pm 2.2$ \\
EM & $7.0^{\mathrm{a}} \pm 3.1$ & $7.2^{\mathrm{a}} \pm 2.1$ & $7.1^{\mathrm{a}} \pm 2.0$ \\
CC & $7.3^{\mathrm{a}} \pm 1.3$ & $7.1^{\mathrm{a}} \pm 1.3$ & $7.1^{\mathrm{a}} \pm 1.9$ \\
CG & $7.5^{\mathrm{a}} \pm 3.1$ & $7.8^{\mathrm{a}} \pm 1.4$ & $7.4^{\mathrm{a}} \pm 1.5$ \\
SB & $7.2^{\mathrm{a}} \pm 3.1$ & $7.8^{\mathrm{a}} \pm 2.7$ & $7.3^{\mathrm{a}} \pm 2.1$ \\
Week 12 & & & \\
CR & $7.0^{\mathrm{a}} \pm 1.1$ & $7.1^{\mathrm{a}} \pm 2.1$ & $6.9^{\mathrm{a}} \pm 2.1$ \\
ES & $6.3^{\mathrm{a}} \pm 1.7$ & $6.5^{\mathrm{a}} \pm 1.0$ & $6.8^{\mathrm{a}} \pm 3.0$ \\
EM & $6.4^{\mathrm{a}} \pm 2.1$ & $6.8^{\mathrm{a}} \pm 1.2$ & $6.7^{\mathrm{a}} \pm 1.3$ \\
CC & $6.1^{\mathrm{a}} \pm 1.0$ & $6.6^{\mathrm{a}} \pm 2.1$ & $6.9^{\mathrm{a}} \pm 2.1$ \\
CG & $6.0^{\mathrm{a}} \pm 2.1$ & $6.5^{\mathrm{a}} \pm 3.1$ & $6.1^{\mathrm{a}} \pm 1.5$ \\
SB & $6.4^{\mathrm{a}} \pm 1.3$ & $6.3^{\mathrm{a}} \pm 1.3$ & $6.1^{\mathrm{a}} \pm 2.0$
\end{tabular}

Week 24

$\begin{array}{llll}\text { CR } & 6.4^{\mathrm{a}} \pm 2.1 & 5.5^{\mathrm{b}} \pm 1.1 & 6.1^{\mathrm{a}} \pm 1.6 \\ \text { ES } & 5.8^{\mathrm{b}} \pm 1.6 & 5.9^{\mathrm{b}} \pm 1.2 & 5.3^{\mathrm{b}} \pm 1.2 \\ \text { EM } & 5.8^{\mathrm{b}} \pm 2.1 & 5.2^{\mathrm{b}} \pm 1.0 & 5.2^{\mathrm{b}} \pm 1.1 \\ \text { CC } & 5.3^{\mathrm{b}} \pm 1.1 & 5.5^{\mathrm{b}} \pm 1.3 & 5.3^{\mathrm{b}} \pm 1.4 \\ \text { CG } & 5.6^{\mathrm{b}} \pm 1.4 & 5.1^{\mathrm{b}} \pm 1.2 & 5.0^{\mathrm{b}} \pm 1.8 \\ \text { SB } & 5.3^{\mathrm{b}} \pm 1.4 & 5.0^{\mathrm{b}} \pm 2.0 & 5.0^{\mathrm{b}} \pm 1.0\end{array}$

Week 36

$\begin{array}{llll}\text { CR } & 4.3^{c} \pm 0.4 & 4.2^{c} \pm 0.7 & 4.1^{c} \pm 1.0 \\ \text { ES } & 4.2^{c} \pm 1.1 & 4.4^{c} \pm 0.3 & 4.0^{c} \pm 1.1 \\ \text { EM } & 4.0^{c} \pm 0.5 & 4.1^{a} \pm 0.0 & 4.8^{c} \pm 0.7 \\ \text { CC } & 4.5^{c} \pm 1.6 & 3.9^{c} \pm 0.2 & 4.1^{c} \pm 1.3 \\ \text { CG } & 4.2^{c} \pm 0.9 & 4.0^{c} \pm 0.7 & 4.1^{c} \pm 1.2 \\ \text { SB } & 3.4^{d} \pm 1.1 & 3.8^{d} \pm 1.1 & 3.3^{d} \pm 0.09\end{array}$

Means within the same columns with different superscript letters are significantly different at $p \leq 0.05$

Key: CR Chloris roxburghiana, ES Eragrostis superba, EM Enteropogon macrostachyus, CC Cenchrus ciliaris, CG Chloris gayana, SB Sorghum sudanense

grass species, while 12 and 24 weeks had $5-7 \%$ CP and 36-week storage had less than $5 \%$ CP. SB had the highest decline $(<4 \%)$ in CP that was significantly different $(p \leq 0.05)$ among the six species at the storage period of 36 weeks. CR showed slightly higher $\mathrm{CP}$ among the six grass species at the three curing periods for the 2- and 12-week storage periods, however, and was not significantly different, but after 24-week storage period, at 1- and 3-day curing, the species showed significant difference among the six species. The 3-day curing had visual color change 
from green to brownish for all the six grass species unlike in the 1- and 2-day period which retained greenish color shades.

\section{Discussion}

The observed lack of significant difference in $\mathrm{CP}$ content across the three curing periods could be attributed to the lower forage moisture content which did not enhance deterioration. The grasses depicted 1-day curing moisture content ranging between 14.5 and $18.5 \%$ at the time of storage; 2 -day curing had $8.0-14.3 \%$ moisture; and 3-day curing having 5.2-11.2 \% moisture level. The 2- and 3-day curing period had moisture levels below $15 \%$ which do not reduce hay quality (Rotz and Muck 1994; Coblentz et al. 2000). During bailing, the temperatures were between 26 and $35{ }^{\circ} \mathrm{C}$, and this might have significantly reduced hay moisture content for the species and hence observed no significant differences in quality across curing periods. However, there was observed changes in hay color in the 3-day curing which turned brownish at bailing unlike the 1- and 2-day curing period which retain some green color. This was attributed to excessive moisture loss through evaporation in the 3-day curing which was also observed to by Dunn and Billingsley (2007) for extended curing periods. Collins et al. $(1995 ; 1997)$ and Arinze et al. (1996) also observed baling at moisture level of greater than $15 \%$ to cause some change in hay color towards brown shades along with microbial growth and heating. Change in color despite not affecting quality has a negative effect on palatability (Dunn and Billingsley 2007). The observed decline in CP with storage periods may be attributed to weathering, microbial, and fungal activities that resulted to fermentation of soluble carbohydrates and hence decline in CP levels in the process. However, this study did not investigate the microbial activity with storage period. Elawad et al. (2003) observed similar findings where CP declined with storage periods for grasses.

The losses in CP under this study can be attributed to weathering, continued respiration of stored grasses, and microbial activity during storage which was observed by Rotz (2003). Other studies attributed changes in CP content of mixed grass hay stored outside for 5 months to weathering (Verma and Nelson 1983; Collins et al. 1997). Enoh et al. (2005) attributed a decline in CP for Hyparrhenia species and cultivated Brachiaria ruziziensis under shade storage conditions to the same factors. The observed high decline of $S$. sudanense in this study could be attributed to its slightly thicker stems that might have reduced curability and hence retained more moisture compared to the other species, hence increased degradation rates by fermentation. Other studies have also reported low drying rates for $S$. sudanense during sun curing (Maiki et al. 1990).

\section{Conclusions}

This study has demonstrated that the 2-3-day curing as practiced in Kenyan rangelands by pastoralists does not significantly affect forage $\mathrm{CP}$; however, at 3 days, it has effects on forage color which may reduce palatability and intake, hence affecting productivity. It is therefore recommended that 1-2-day curing be adopted under similar environments in the arid and semi-rangelands. Lastly, the study shows hay deterioration increases with storage duration, where 12-week indoor storage maintains $\mathrm{CP}$ above $6 \%$ which is the recommended minimum content for livestock maintenance; beyond this storage period, $\mathrm{CP}$ declines drastically to $<5 \%$ making it poor diet for animals.

\section{Competing interests}

The authors declare that they have no competing interests.

\section{Authors' contributions}

$\mathrm{KO}$ designed the study, collected the data, participated in the data analysis, and drafted the manuscript write-up and revision. KR was part of the study design, data cleaning, and analysis. KG was part of the data collection and laboratory analysis. MS was part of the data analysis and contributed to the result write-up and manuscript editing. WR was involved in the manuscript writing, participated in the result interpretation, and was also part of the data collection team. All authors read and approved the final manuscript.

\section{Acknowledgements}

This work was supported by the National Irrigation Board (NIB) Kenya, Government of Kenya through the National Council of Science, Technology and Innovation (NACOSTI), German Academic Exchange Service (DAAD), and the Centre for Sustainable Dryland Ecosystems and Societies (CSDES)-University of Nairobi, Kenya. I also acknowledge Ann Kimende, Benjamin Kyalo, and Dismon Ambale from the University of Nairobi for helping with the lab analysis in this study. Lastly, we thank Biosciences eastern and central Africa at the International Livestock Research Institute (BecA-ILRI) HubNairobi, Kenya, for providing scientific writing training that led to the development of this manuscript.

\section{Author details}

'Department of Land Resource Management and Agricultural Technology, Range Management Section, University of Nairobi, P.O. Box 209053-00625, Nairobi, Kenya. ${ }^{2}$ National Irrigation Board, Mwea Irrigation Agricultural Development (MIAD) Centre, P.O. Box 210, 10303 Wanguru, Kenya.

Received: 30 October 2015 Accepted: 30 March 2016

Published online: 06 April 2016

\footnotetext{
References

AOAC (1990) Official methods of analysis, 15th edn. Association of Official Analytical Chemists, Arlington

AOAC (2005) Official methods of analysis of the association of analytical chemists, 18th edn. AOAC, Gathersburg

Arinze EA, Sokhansanj S, Schoenau GJ, Trauttmansdorff FG (1996) Experimental evaluation, simulation and optimization of a commercial heated-air batch hay drier: part 1, drier functional performance, product quality, and economic analysis of drying. Journal of Agricultural Engineering Research 63(4):301-314

Bernués A, Ruiz R, Olaizola A, Villalba D, Casasús I (2011) Sustainability of pasture-based livestock farming systems in the European Mediterranean context: synergies and trade-offs. Livestock Science 139(1):44-57

Buskirk DD, Zanella AJ, Harrigan TM, Van Lente JL, Gnagey LM, Kaerche MJ, Buskirk DD, Zanella AJ, Harrigan TM, Van Lente JL, Gnagey LM, Kaerche MJ (2003) Large round bale feeder design affects hay utilization and beef cow behaviour. Journal of Animal Science 81:109-115, https://dl.sciencesocieties. org/publications/jas/abstracts/81/1/109. Accesses 17 Mar 2014
} 
Coblentz WK, Turner JE, Scarbrough DA, Lesmeister KE, Johnson ZB, Kellogg DW, Weyers JS (2000) Storage characteristics and nutritive value changes in bermudagrass hay as affected by moisture content and density of rectangular bales. Crop science 40(5):1375-1383

Collins M, Swetnam LD, Turner GM, Hancock JN, Shearer SA (1995) Storage method effects on dry matter and quality losses of tall fescue round bales. Journal of production agriculture 8(4):507-514

Collins M, Ditsch D, Henning JC, Turner LW, Isaacs S, Lacefield GD (1997) Round bale hay storage in Kentucky, Univ. of Kentucky, Coop. Ext. Publ., Leaflet AGR-171

Dunn MT, Billingsley J (2007) Mechatronics and machine vision in practice, 2007. M2VIP 2007. 14th International Conference on (pp. 179-184). IEEE

Elawad S, Kumagai H, Mitani K (2003) Measurement and estimation of changes in nutrient composition and nutrient losses during hay and silage making in field curing. Grassland Science 49(2):117-124

Enoh MB, Kijora C, Peters KJ, Tanya VN, Fonkem D, Mbanya J (2005) Investigation on change of forage quality at harvesting, during hay making and storage of hay harvested at different growth stages in the Adamawa plateau of Cameroon. Livestock Research for Rural Development 17(5):1-6

GOK (2005) Tana River District Strategic Plan 2005-2010 for Implementation of the National Population Policy for Sustainable Development. Available online. http://ncpdke.org/strategicplans/TanaRiver.pdf. Accessed 25 June 2012.

ISTA (1976) International rules for seed testing. Seed Science and Technology 4: 23-28.

Mackie PG (2004) U.S. Patent No. 6,711,996. U.S. Patent and Trademark Office, Washington, http://tinyurl.com/n7mef3e. Accessed 10 Jan 2014

Maiki T, Tanaka S, Kawamura O (1990) Dry matter yields and drying rates during sun curing for 7 tropical grasses for haymaking in southern Kyushu. Bulletin of the Faculty of Agriculture, Miyazaki University 36(2):373-382

McDermott JJ, Staal SJ, Freeman HA, Herrero M, Van de Steeg JA (2010) Sustaining intensification of smallholder livestock systems in the tropics. Livestock science 130(1):95-109

Mganga KZ, Musimba NKR, Nyariki DM, Nyangito MM, Mwang'ombe AW (2015) The choice of grass species to combat desertification in semi-arid Kenyan rangelands is greatly influenced by their forage value for livestock. Grass and Forage Science 70(1):161-167

Ndathi AJ, Nyangito MM, Musimba NK, Mitaru BN (2011) Climate variability and dry season ruminant livestock feeding strategies in Southeastern Kenya

Ndathi AJ, Nyangito MM, Musimba NK, Mitaru BN (2012) Farmers' preference and nutritive value of selected indigenous plant feed materials for cattle in drylands of south-eastern Kenya. Livestock research for rural development 24 (2) 2012. http://www.Irrd.cipav.org.co//rrd24/2/ndat24028.htm. Accessed June 15th 2015.

Ndathi AJ, Muthiani EN, Ndung'u JN, Ogillo BP, Kimitei RK, Manyeki JK, Mnene WN (2013) Feed resources and utilization strategies in selected pastoral and agropastoral communities in Kenya. Livestock Research for Rural Development 25:221

Rankin M, Undersander D (2004) Rain damage to forage during hay and silage making., http://fyi.uwex.edu/forage/files/2014/01/Raindam.pdf. Accessed 12 Jun 2013

Roberts CA (1995) Microbiology of stored forages. Page 21. In: Moore KJ, Peterson MA (eds) Post-Harvest Physiology and Preservation of Forages. CSSA Special Publication No. 22. Am. Soc. Agron., Crop Sci. Soc. Am. and Soil Sci. Soc. Am, Madison

Roberts CA, Kallenbach RL, Hill NS, Rottinghaus GE, Evans TJ (2009) Ergot alkaloid concentrations in tall fescue hay during production and storage. Crop Science 49(4):1496-1502

Rotz CA (2003) How to maintain forage quality during harvest and storage. Advances in Dairy Tecnology 15:227-239

Rotz CA, Abrams SM (1988) Losses and quality changes during alfalfa hay harvest and storage. Transactions of the ASAE 31(2):350-0355

Rotz CA, Muck RE (1994) Changes in forage quality during harvest and storage. Pages 828-868. In: Nat. Conf. on Forage Quality, Evaluation, and Utilization, Fahey GC, Collins M, Mertens DR, Moser LE (eds) Forage Quality, Evaluation, and Utilization., Univ. Nebraska, Lincoln. ASA-CSSASSSA, Madison, WI

Suttie JM (2000) Hay and straw conservation: for small-scale farming and pastoral conditions (No. 29). Food \& Agriculture Organization, http://tinyurl.com/hx2dv3r. Accessed may 23rd 2014
Tangni EK, Pussemier L, Van Hove F (2013) Mycotoxin contaminating maize and grass silages for dairy cattle feeding: current state and challenges. Journal of Animal Science Adv 3(10):492-511

Thornton PK, Herrero M (2014) Climate change adaptation in mixed crop-livestock systems in developing countries. Global Food Security 3(2):99-107

Verma LR, Nelson BD (1983) Changes in round bales during storage Transactions of the American Society of Agricultural Engineers (ASAE), 26(2):328-0332.

\section{Submit your manuscript to a SpringerOpen ${ }^{\circ}$ journal and benefit from:}

- Convenient online submission

- Rigorous peer review

- Immediate publication on acceptance

- Open access: articles freely available online

- High visibility within the field

- Retaining the copyright to your article

Submit your next manuscript at $>$ springeropen.com 